\title{
Experimental Study on Individual Taxpayer: Motivational Posture and Peer Reporting Behavior
}

\author{
Elen Puspitasari ${ }^{1}{ }^{\bowtie}$ Yeye Susilowati $^{1}$, Wahyu Meiranto ${ }^{2}$ \\ ${ }^{1}$ Faculty of Economic and Business, University of Stikubank, Semarang, Indonesia \\ ${ }^{2}$ Faculty of Economic and Business, University of Diponegoro, Semarang, Indonesia
}

\section{Info Article}

History Article:

Received Desember 2016

Approved Januari 2017

Published Maret 2017

\section{Keywords:}

Motivational Postures; Peer Re-

porting Behavior; Tax Compliance

Decisions; Experiment.

\begin{abstract}
The effect of motivational postures and tax reporting behavior of one's peers on taxpayer compliance was examined in this experimental study. This experimental research was conducted under the circumstances arranged and direct manipulation on taxpayer external factor, namely the independent variable is peer reporting behavior, so it can be determined causality effect of the independent variable on the dependent. The respondent is 81 taxpayers whose run the small business. A motivational posture was measured by using 29 statements developed by Braithwaite. Analysis of Covariance is used because this research conducting Quasi Experimental Design Between-Subject with Covariate with random assignment method. Peer reporting behavior as an experimental variable consists of two level treatments. The result shows that the posture of motivation Indonesian taxpayers' as a concomitant factor does not affect tax compliance decisions. Furthermore, this study provides evidence that peer reporting behavior were significant factors in explaining the experimental reporting decision. The findings of this study are expected to provide discourse to the government to improve tax compliance decisions in Indonesia in terms of posture motivation and peer reporting behavior among taxpayers.
\end{abstract}

\section{Studi Eksperimental tentang Wajib Pajak Orang Pribadi: Sikap Motivasi dan Perilaku Pelaporan Sejawat}

\begin{abstract}
Abstrak
Pengaruh sikap motivasi dan perilaku pelaporan pajak teman sejawat terhadap kepatuhan wajib pajak diteliti dalam penelitian ini. Penelitian dilakukan dengan menggunakan manipulasi langsung pada faktor eksternal pembayar pajak, yaitu variabel independen, sehingga dapat ditentukan efek kausalitas dari variabel independen terhadap dependen. Responden adalah 81 pembayar pajak yang menjalankan usaha kecil. Sikap motivasi diukur dengan menggunakan 29 pernyataan yang dikembangkan oleh Braithwaite. Analisis Kovarian digunakan karena penelitian menggunakan desain Quasi Experimental antar subjek dengan metode random assignment. Perilaku pelaporan rekan sejawat sebagai variabel eksperimen terdiri dari dua tingkat perlakuan. Hasil menunjukkan postur motivasi pembayar pajak Indonesia sebagai tidak mempengaruhi keputusan kepatuhan wajib pajak. Selanjutnya, penelitian ini memberikan bukti bahwa perilaku pelaporan teman sejawat merupakan faktor signifikan dalam menjelaskan keputusan pelaporan eksperimental. Hasil penelitian ini diharapkan dapat memberikan wacana kepada pemerintah untuk memperbaiki keputusan kepatuhan pajak di Indonesia dalam hal sikap motivasi dan perilaku pelaporan sejawat antar wajib pajak.
\end{abstract}

JEL Classification: G1, G21 


\section{INTRODUCTION}

Taxation is one of the important elements in managing national income, especially in developed countries and has played an important role in civilized societies since their birth thousands years ago (Lymer \& Oats, 2009). Most of the countries around the world develop their nation primarily from income tax sources, either direct taxes or indirect taxes. Hence, compliance in paying taxes is an important factor to increase state revenue, because taxes are important sources of state revenue. Ministry of Finance Republic of Indonesia reported that approximately 78.89 percent of total state revenues will be derived from tax revenues.

The Organization for Economic and Cooperation Development (OECD) found that tax compliance is an important issue. Tax compliance is an issue related to how to enter and report all information on time, filling in the correct amount of taxes owed and pay taxes on time without any coercive action.

Tax compliance will always be interesting to study, although some previous researchers have tried to develop a model of tax compliance (Alabede et al., 2011). Studies on tax compliance decisions will continue to evolve broadly by using a variety of theoretical approaches, variables, and other research methods (Torgler, 2002). Test results empirically and theoretically find that tax compliance is influenced by various factors (Alm et al., 2012).

In order to increase tax revenues, the Indonesian government has run several reforms in the field of taxation ( $\operatorname{tax}$ reform). For example, the government launched Self Assessment System (SAS) to replace Official Assessment System (OAS). In addition, since 2002 the government has implemented the Modernization Tax Administration (MTA). One of the purposes of the MTA is to provide ease and simplicity in calculating the final income. The enactment of Government Regulation (PP) number 46 is one of government commitment to implement MTA.

Ease and simplification of the tax code in a particular income tax from business with a certain turnover are a response to taxpayer complaints towards the difficulty of calculating their earnings. The enactment of Government Regulation Number 46 year 2013 (PP number 46), is the simplification of the process to ensure taxpayers would easily pay their taxes. The object of the income subject to income tax which is final income in that PP (effective from July 1,2013 ) is the income of the business derived from the taxpayer with gross turnover no more than 4.8 billion IDR per year. The final income is due to the application of the $1 \%$ (one percent) tax rate on the circulation of business every month.

A difficulty in the empirical study of tax compliance is the availability of detailed and reliable information regarding the choice of the individual taxpayer compliance decisions. Measurement in the OECD Tax Compliance Guidance Series (OECD, 2001) provides recommendations for using design of experiments which are considered as the ideal data collection methods in the study of tax compliance. The experimental design will lead researchers to find a causal relationship that affects the behavior of taxpayers in tax compliance decisions.

This research was conducted by using motivational postures theory as a new approach in determining the tax compliance. It uses the method of individual psychological taxpayer, which was developed by Valerie Braithwaite in order to improve tax compliance. Posture motivation describes the stances or mental attitude that taxpayers openly express in their relationships with the tax authority (Braithwaite et al., 2007).

Motivational postures are interconnected sets of beliefs and attitudes that are consciously held and openly shared with others. Moreover, motivational postures are the signals that people send to authorities, including criminal justice authorities, to indicate their liking for that authority and their willingness to defer to the authority's rules and processes. These signals change in response to the actions of authority.

Five motivational postures have been identified as important in the context of taxati- 
Elen Puspitasari, et al. / Experimental Study on Individual Taxpayer:..

on compliance are commitment, capitulation, resistance, disengagement, and game playing. The two postures that reflect an overall positive orientation to authority are commitment and capitulation. While the three other postures, i.e. resistance, disengagement, and game playing posture that reflect the defiance orientation.

Motivational postures are the signals that are sent by individuals and groups; they can be read by authorities, and can be used to establish better working relationships (Braithwaite, 2014). The Australian Taxation Office (ATO) compliance model adapted motivational postures from Braithwaite (Hofmann et al., 2008). The ATO compliance model show tax authorities should appropriately respond to taxpayers holding particular motivational postures.

Therefore, this study tries to use motivational postures as an intrinsic factor of individual taxpayers in Indonesia along with extrinsic factors, namely peers reporting behavior in a model of tax compliance decisions of experimental research methods. Due the motivational posture an intrinsic factor that rises from individual taxpayers, the posture of motivation in this study was not given treatment as experimental variables. Accordingly, this experimental study uses the posture of motivation as a covariance in the model of tax compliance decisions.

Peer reporting behavior as external factor of taxpayers in this study using the reference theory. Behavioral studies revealed that peer groups have a strong impact on the behavior, preferences and values of the individual's personality. Some of the tax compliance literature suggests that peer reporting behavior is one of the variables that determine tax compliance decisions derived from situational factors, as proposed by Bloomquist (2011); Alm et al. (2012); Palil et al. (2013); and Alm et al. (2016).

Tax compliance is influenced by the peer, such as friends, family, and the people are around him (Chau \& Leung, 2009). Chan et al. (2000) states that the taxpayer will decide not to obey for a consistent environment to not obey. However, the findings of Hite (1988) demonstrate empirically that the reporting behavior of peer variables were used as experimental variables in an experiment that did not affect the participants' tax compliance reporting decisions.

Decision of tax compliance as the dependent variable in a study is a complicated decision, so that the existence of independent variables peer reporting behavior, which is thought to be external factors that influence the decision of tax compliance, there is still a possibility that other factors also affect, namely posture motivation in the individual taxpayer. Research which has the purpose to develop a model of tax compliance is necessary, especially for a country that adheres to the self assessment system.

\section{Hypothesis Development}

Motivational Postures and Tax Compliance Decisions. Several empirical studies on motivational postures in particular have published by Braithwaite to the book: Taxing Democrazy in 2003. The results showed that the posture (the mental attitude of individual taxpayers) is different can affect tax compliance decisions. Motivational posture changes according to the circumstances of the relationship that is created between the taxpayer and the tax authority. Braithwaite suggests that these two postures that reflect an overall positive orientation to authority are commitment and capitulation.

Commitment reflects beliefs about the desirability of tax systems and feelings of moral obligation to take action in the interest of the collective and pay one's tax with good will. Capitulation reflects acceptance of the tax office as the legitimate authority and the feeling that the tax office is a benign power as long as one acts properly and defers to its authority.

Further, Braithwaite (2003) states that there are contrasts to these postures of deference are three postures of defiance. The first is the familiar posture of resistance. Resistance reflects doubts about the intentions of the tax office to behave cooperatively and benignly towards those it dominates and provides the rhetoric for calling on taxpayers to be watchful, to strive for their rights, and to curb tax office power. Disengagement is also motivational posture that 
communicates resistance, but here the disenchantment is more widespread, and individuals and groups have moved beyond seeing any point in challenging the authorities.

The tax office and the tax system are beyond redemption for the disengaged citizen, the main objective being to keep both socially distant and blocked from view. The fifth posture is game playing. Game playing was included as a motivational posture for the purposes of testing whether or not players consciously adopted this style of engagement with the tax system and the tax office.

Therefore, it is necessary to use a study to test whether the posture of commitment and capitulation that has a positive orientation, and posture of resistance, disengagement and game playing that has a defiance orientation will affect the level of tax compliance decisions.

H1: Tax Compliance Decisions will be higher in the taxpayer has a positive oriented motivation posture, when compared with the taxpayer who has a defiance oriented motivation posture.

Peer Reporting Behavior and Tax Compliance Decisions. Factor of peer influences or referents groups can be obtained from family, friends and colleagues (friendly persuasion). Peer influences are thought to play a role in the decision of taxpayers for tax evasion (Palil, 2010). Hite (1988) and Efebera et al. (2014) stated that a taxpayer commitment in terms of social norms on tax compliance becomes weak, when someone who has significance (peer or referent) to the taxpayers tax evasion behaviors.

The exposure has been supported by the following exposure. Peer (referents) has a strong influence, when peer (referent) that plays an important role and be a valid reason for someone to obey (Palil, 2005). The behavior and attitude of the people who were around the taxpayer and considered important (referent) by the taxpayer, such as family, spouse, peers, and colleagues (peer) is thought to have a strong influence on tax compliance decisions (Palil, 2010).
H2: Tax Compliance Decisions will be higher on the taxpayer to obtain the influences of peer reporting behavior obedient (compliers), when compared with the taxpayer to obtain the influence of peer reporting behavior of non-compliance.

\section{METHOD}

\section{Research Setting}

This experiment is a research study using laboratory experiments settings. These experimental researches was conducted under the circumstances arranged and direct manipulation on taxpayer external factor, namely the independent variable is peer reporting behavior, so it can be determined causality effect of the independent variable on the dependent. Internal factors taxpayer in this study is a motivational posture variable which is as concomitant factors (covariates) which have the possibility of affecting (confounding effect) dependent variable tax compliance decisions. Therefore, concomitant factors are not able to be controlled by the experimenter. Thus, this experimental study is methodologically called a quasi-experimental design.

\section{Subject of Experiments}

Experimental subjects or participants were used in this study amount of 81 individual taxpayer's who has income derived from the conduct of business itself with gross turnover no more than 4,8 billion IDR per year. They have a Taxpayer Identification Number and have experience in reporting his tax liability. This is conducted in order to eliminate the weakness of experimental research in terms of external validity is low. Selection of research participants in this experiment was in accordance with the basic principles of search participants.

Round of experiments conducted on five times by using the class of post graduate programs in public and private universities in the Semarang city, Central Java, Indonesia. After the measurement of motivational posture of 
Elen Puspitasari, et al. / Experimental Study on Individual Taxpayer:..

Table 1. Round of Experiments

\begin{tabular}{lllllll}
\hline \multirow{2}{*}{ Round } & Gender & & PostMotiv & & Peer & \\
\cline { 2 - 7 } & Male & Female & Positive & Defiance & Comp & Non \\
\hline 1 & 7 & 9 & 15 & 1 & 9 & 7 \\
2 & 9 & 8 & 13 & 4 & 8 & 9 \\
3 & 10 & 8 & 9 & 9 & 8 & 10 \\
4 & 11 & 5 & 12 & 4 & 9 & 7 \\
5 & 5 & 9 & 11 & 3 & 6 & 8 \\
\hline Total Partici- & 42 & 39 & 60 & 21 & 40 & 41 \\
\cline { 2 - 8 } pant & 81 & & 81 & & 81 & \\
\hline
\end{tabular}

each participant, it can be seen that 60 participants had a positive oriented motivation posture. While the 21 participants who have defiance orientation (Table 1). Treatment for peer reporting behavior as a variable experiment carried out randomly to the experimental subject.

\section{Design of Experiments}

The design used in this study, namely Quasi Experimental Design Between-Subject with Covariate with Random Assignment Method. Variable posture motivation is the covariate variables, i.e. variables which cannot be controlled in a research experiment, but these variables are likely to affect the outcome of the dependent variable. Independent variables who obtained in this experimental research are peers reporting behavior that will be divided into two treatment levels. Each participant will receive only one treatment level of each of the experimental variable.

\section{Research Variables}

The dependent variable in this study is the decision of Tax Compliance, which is an ethical decision made by the taxpayer to declare the amount of income to be taxed. Measurement of tax compliance decisions in this experimental research was obtained from participants in the decision or response reported total income of the level of treatment or manipulation is given by the percentage. The statements on Appendix 2 and 3 based on the scenario of tax compliance decisions on media experiment: "how much revenue (in percentage) would you report it?"
The independent variable in this study is the external and internal factors taxpayer. External factors are the independent variables are getting treatment, or named as an experimental variable, i.e. the variable peer reporting behavior. While internal factor of taxpayers is variable posture motivation, where this variable is not carried out at the level of treatment by the experimenter (covariate variable).

Peer reporting behavior is defined as external influences acquired by the taxpayer from income reporting decisions are derived from a friend or colleague or people nearby (referent group) that may affect tax compliance decisions. Manipulation conducted by providing information to participants about the situation overview of peer behavior on experimental media. Variable peer reporting behavior is nonmetric variables were measured using two categories, namely category 1 (PEC) for reporting peer obedient behavior (compliers), and category 2 (PEN) for peer reporting behavior that is not compliant (no compliers).

Measurement of motivational postures conducted in the early stages of the experiment using the instrument motivational postures in the form of a questionnaire with 29 statements. The response scale was a 1-5 Likert scale, 1 (strongly disagree) to 5 (strongly agree) developed by Braithwaite. The statements representing motivational postures of commitment, resistance, disengagement, and game playing consists of 8 statement for posture commitment, 5 statement of capitulation posture, 6 statement to measure posture of resistance, 5 statements to measure posture disengagement, and 5 statements for measure game playing posture. 


\section{Experimental Procedures}

Beginning of the experiment according to the place and time specified. The first stage is to establish internal validity environment, where the convenience of the participants in the following stages of the experiment is preferred. The first stage is the introduction, whereas the experimenter begins with an introduction to the participants, including the presentation of research objectives and a statement as independent researchers rather than as part of the tax authorities. Experimenter gives an explanation of the experimental procedure to be run.

Submission stage is the second stage that distributing a questionnaire consists of demographic data and a list of motivational posture statement. Experimenter said that the list of statements contained in the questionnaire is not an exam, so participants need not worry about the resulting score. Participants require a period of sixty minutes to complete this phase.

Then, phase manipulation experiments, in which each participant will receive one treatment level for the experimental variable (between subjects). Participants at this stage of the experimental media were taking form of experimental stimulus in the form of case or scenario peers reporting behavior from the box experiment, randomly. The time is given to the participants to make decisions based on the amount of income reported treatment (manipulation) peers reporting behavior that is ten minutes.

This experimental research using paper and pencil test method, which is a way that is done by using a questionnaire which was answered manually. This method is simple and easy. The whole assignment for each phase is done randomly in an experimental area took place, and supervised by the experimenter during the process underway.

\section{Techniques Analysis}

Manipulation checks carried out on the data obtained from the participants, whether participants know and understand the correct treatment are given to the participants during the experiment.The results showed that 100 percent of participants understand the treatment given during the experimental research. Hypothesis testing is conducted by using ANCOVA (Analysis of Covariance).

The model equations (1) are used to test the first and second hypothesis with BetweenSubject design with covariates are as follows:

$$
\text { DECISION }_{i j}=\mu+\propto \text { PEER }_{i}+\beta \text { POSTMOTIV }_{j}+\varepsilon_{i j}
$$

Where:

\begin{tabular}{|c|c|}
\hline DECISION $_{\mathrm{ij}}$ & : Tax Compliance Decisions \\
\hline$\mu$ & : Mean general \\
\hline $\operatorname{aPEER}_{\mathrm{i}}$ & $\begin{array}{l}\text { : The effect of level i of factor } \\
\text { peer reporting behavior (Com- } \\
\text { pliers and no compliers) }\end{array}$ \\
\hline$\beta$ POSTMOTI & $\begin{array}{l}V_{i}: \text { Regression coefficient (ef- } \\
\text { fect) of the value of the covari- } \\
\text { ate Posture Motivation }\end{array}$ \\
\hline$\varepsilon_{\mathrm{ij}}$ & : Random error \\
\hline
\end{tabular}

Table 2. Result of ANCOVA Dependent Variable: DECISION

\begin{tabular}{lllll}
\hline Source & Type III Sum of Squares & Mean Square & F & Sig. \\
\hline Corrected Model & $2.104,717^{\mathrm{a}}$ & $1.052,359$ & 8,626 & 0,000 \\
Intercept & $66.025,548$ & $66.025,548$ & 541,178 & 0,000 \\
PEER & $2.097,301$ & $2.097,301$ & 17,191 & 0,000 \\
POSTMTV & 39,080 & 39,080 & 0,320 & 0,573 \\
Error & $9.516,270$ & 122,003 & & \\
Total & $653.400,000$ & & & \\
Corrected Total & $11.620,988$ & & & \\
\hline
\end{tabular}

a. R Squared = 0,181 (Adjusted R Squared = 0,160) 
Elen Puspitasari, et al. / Experimental Study on Individual Taxpayer:..

Analysis of the effect of independent variable on the dependent variable tax compliance decision is a step deeper proof of the hypothesis that has been proposed, so it needs to be followed by an analysis of the Pairwise Comparisons, which is the result of the Estimated Marginal Means. However, the placement of variable posture motivation in step of ANCOVA giving the consequence that the output of SPSS does not produce Pairwise Comparisons of Estimated Marginal Means for the covariate variables, so that further testing of the hypothesis using the Independent-Samples $t$ Test.

\section{RESULT AND DISCUSSION}

The assumptions of ANCOVA, such as homogeneity of variance, linearity, normality of the data, and lack of fit test in this study are in accordance with the requirements. Corrected models in Table 2 were obtained from Tests of Between-Subjects Effects showed the significance of 0.000 is far below 0.05 , then at the 95 percent confidence level can be concluded that the posture of motivation, and peer behavior reporting effect on tax compliance decisions simultaneously.

Hypothesis test results obtained from the ANCOVA in Table 2 shows that the main effect of variable posture motivation (POSTMTV) with $F$ value of 0.320 and $p=0.573$ statistically is not significant at the 0.05 level. Meanwhile, variable Peer Reporting Behavior (PEER) significantly influences the decision of Tax Compliance with $\mathrm{F}$ value of 17.191 and a probability of 0.000. The results of these tests indicate a difference significant tax compliance decisions at the level (treatment) of peer reporting behavior, but there were no differences in significant tax compliance decisions on differences in motivational postures taxpayers.

In Table3, $t$-values are shown in equal variance assumed is -0.225 with a probability of 0.823 (two-tailed). Test the hypothesis in this study was conducted with a one-tailed $\mathrm{H} 1: \mu 1>$ $\mu 2$, with a p-value to 0.4115 which is greater than $\alpha=0.05$ level is not significant. It can be concluded that the decision of tax compliance among taxpayers who have a positive oriented motivation posture are no different from taxpayer who has the posture of defiance oriented motivation. Thus there is no statistical support for the Hypothesis1 (H1).The results of this study indicate that the approach of motivational postures theory which states that the taxpayer who has the posture of motivation with a positive orientation (commitment and capitulation) illustrates that taxpayers tend to be more compliant are not proven in this study. Therefore, this study does not support the statement of Braithwaite, which states that the taxpayer who has the posture motivation of defiance oriented (resistance, disengagement, and playing games) tend to behave disobedient.

Estimated Marginal Means in Table 4 shows the average tax compliance decisions based on the influence of peer reporting behavior. A taxpayer who obtained the influence of peer reporting behavior obedient (compliers)

Table 3. Tax Compliance Decisions Viewed from Taxpayer Motivation Posture

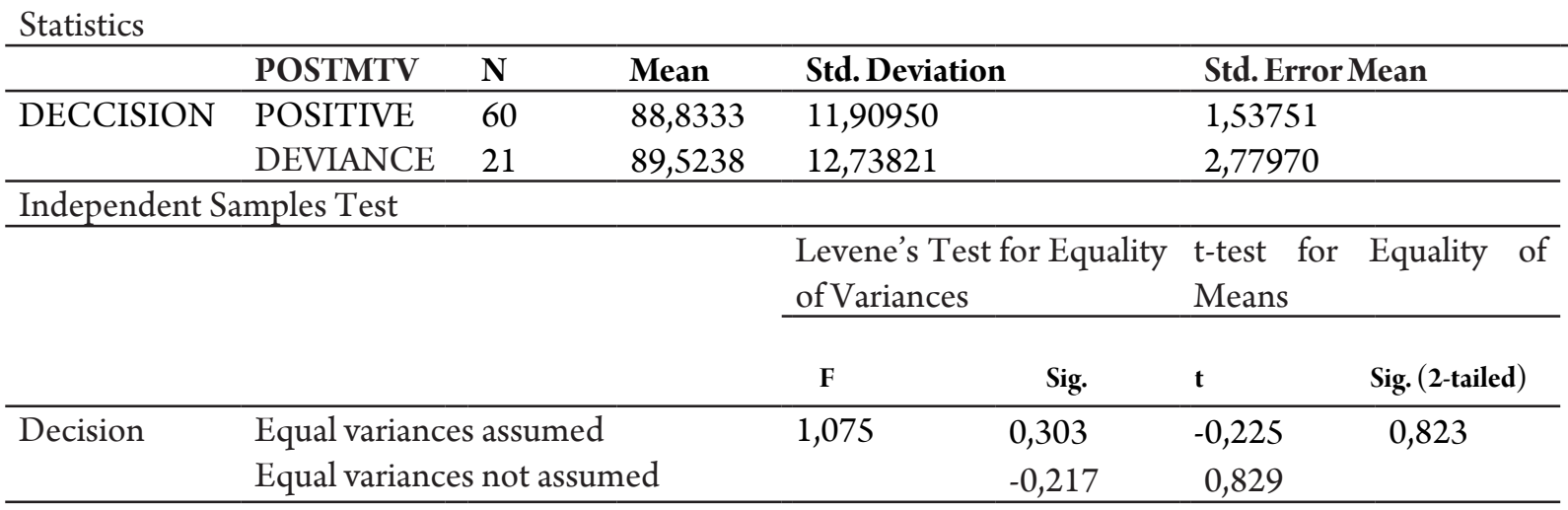


Table 4. Tax Compliance Decisions Viewed from Peer Reporting Behavior

Dependent Variable: DECISION

\begin{tabular}{|c|c|c|c|c|c|c|}
\hline \multirow[b]{2}{*}{ PEER } & \multirow[b]{2}{*}{ Mean } & \multirow[t]{2}{*}{ Std. Error } & \multicolumn{2}{|c|}{ 95\% Confidence Interval } & \multirow{2}{*}{\multicolumn{2}{|c|}{ Upper Bound }} \\
\hline & & & Lower Bound & & & \\
\hline compliers & $94.179^{a}$ & 1.749 & 90.697 & & & 97.662 \\
\hline noncompliers & $83.971^{\mathrm{a}}$ & 1.728 & 80.532 & & & 87.411 \\
\hline \multicolumn{7}{|c|}{$\begin{array}{l}\text { Pairwise Comparisons } \\
\text { Dependent Variable: decision }\end{array}$} \\
\hline (I) PEER & (J) PEER & & Mean Difference (I-J) & Std. Error & Sig. ${ }^{b}$ & \\
\hline Compliers & noncompliers & & $10.208^{*}$ & 2.462 & 0.000 & \\
\hline
\end{tabular}

has an average value (mean) of the decision is higher $(\mu=94.179)$, compared to the taxpayer that is on the influence of peer reporting behavior of non-compliance (no compliers) with an average value (mean) tax compliance decisions by 83.971 percent and significant at $\mathrm{p}=0.000$.

The results of this statistical analysis supports Hypotheses $2(\mathrm{H} 2)$ which states that there are differences in tax compliance decision to the taxpayer is given the influence of peer reporting behavior that is compliant with the taxpayer to obtain the influence of peer reporting behavior of non-compliance. Thus, it can be concluded that a peer who obey will affect tax compliance decisions of participants to be more obedient, when compared to participants who influenced peers that do not comply.

The influence of the reference group in this experiment manipulated the media to influences the participants' tax compliance decisions. It is intended to prove that when a person is an individual's perception is influenced by the behavior of other people that are considered important (referents), it will encourage a behavior that deviating decision. This means a compliers taxpayer behavior will result in decisions that deviate, if the taxpayer is in the disobedient group referents, and otherwise.

\section{CONCLUSIONAND RECOMMENDATION}

This study uses the individual taxpayer's who has income derived from the conduct of business itself with the gross turnover of no more than 4.8 billion USD per year as experi- mental subjects. It is intended to get a real condition of the tax compliance decisions of the individual taxpayers. Based on the results of hypothesis testing, either by using ANCOVA and Independent Sample T-Test, motivational posture of participants in this research does not affect tax compliance decisions. Decision of tax compliance among taxpayers who have a positive oriented motivation posture is not different from compliance decision of the taxpayer who has the posture motivation of defiance oriented. This indicates that the participants in this research consciously committed to be part of the mission of the regulator to collect the tax from the taxpayer, despite not reached 100 percent. Thus, it can be stated that scores of tax compliance decisions of participants in this study have not been shown as a reflection of the compliant (obedient) taxpayers.

The interesting thing in this study is the mean of tax compliance decisions Taxpayers who have positively oriented posture (88.83) slightly lower than the mean (89.52) of tax compliance decisions Taxpayers who have defiance oriented posture. Therefore, motivational postures become increasingly attractive to the research agenda of tax compliance decisions in the future, with different designs and settings. Moreover, posture motivation as a new approach in the study of tax compliance in Indonesia. Future research can add other intrinsic factors of taxpayers, such as taxation knowledge and risk preferences of taxpayers.

Taxpayers who obtain treatment an obedient peer reporting behavior (compliers) has 
Elen Puspitasari, et al. / Experimental Study on Individual Taxpayer:..

a tax compliance decision higher than the taxpayer, given peer reporting behavior treatment non-compliance (noncompliers). Therefore, peer reporting behavior also determine the behavior of the taxpayer's reporting decision. The existence of a peer in a person's life affects their behaviour and decisions.

\section{REFERENCES}

Alabede, James O., Ariffin, Z.Z \& Idris, K. M. 2011. Individual Taxpayers' Attitude and Compliance Behavior in Nigeria: The Moderating Role of Financial Condition and Risk Preference. Journal of Accounting and Taxation. 3 (5): 91-104.

Alm, J., Kirchler, E \& Muehlbacher, S. 2012. Combining Psychology and Economics in the Analysis of Compliance: From Enforcement to Cooperation. Economic Analysis \& Policy. 42 (2): 133-151.

Alm, J., Bloomquist, K. M \& McKee, M. 2015. The External Validity of Tax Compliance Experiments. Economic Inquiry. 53 (4): 1170-1186

Alm, J., Bloomquist, K. M \& McKee, M. 2016. When You Know Your Neighbour Pays Taxes: Information, Peer Effects, and Tax Compliance. Fiscal Studies.

Bloomquist, K. M. 2011. Tax compliance as an evolutionary coordination game: An agentbased approach. Public Finance Review. 39 (1): 2549.

Braithwaite, V. 2003. Dancing with Tax Authorities: Motivational Postures and Non-Compliant Actions. Taxing democracy. 15-39.

Braithwaite, V., Murphy, K \& Reinhart, M. 2007. Taxation threat, motivational postures, and responsive regulation. Law \& Policy. 29 (1): 137-158.

Braithwaite, V. 2014. Defiance \& Motivational Postures. Encyclopedia of Criminology and Criminal Justice. New York: Springer Science Business Media.

Chan, C. W., Troutman, C. S \& Bryan, D. 2000. An Expanded Model of Taxpayer Compliance: Empirical Evidence from the United
States and Hongkong. Journal of International Accounting, Auditing, Taxation. 9 (2): 83-103.

Chau, G \& Leung, P. 2009. A Critical Review of Fischer Tax Compliance Model: A Research Synthesis. Journal of Accounting and Taxation. 1: 34-40.

Efebera, H., Hayes, D. C., Hunton, J. E \& O’ Neil, C. 2014. Tax Compliance Intentions of Low Income Individual Taxpayers. Advances in Accounting Behavioral Research. 7: 1-25.

Galbiati, R \& Zanella, G. 2012. The Tax Evasion Social Multiplier: Evidence from Italy. Journal of Public Economics. 96 (5-6): 485-494.

Hite. 1988. The Effect of Peer Reporting Behavior on Taxpayer Compliance. Journal of The American Taxation Association. Spring.

Hofmann, E., Hoelzl, E \& Kirchler, E. 2008. Preconditions of Voluntary Tax Compliance: Knowledge and Evaluation of Taxation, Norms, Fairness, and Motivation to Cooperate. Journal of Psychology. 216 (4): 209-217.

Lymer, A \& Oats, L. 2009. Taxation: Policy and Practice. 16th ed. Birmingham: Fiscal Publications.

OECD. 2001. Organization for Economic and Cooperation Development, Compliance Measurement - Practice Note: 1-23.

Palil, M. R. 2005. Does Tax Knowledge Matters in Self-Assesment Systems? Evidence from Malaysian Tax Administrative. The Journal of American Academy of Business, Cambridge. 2: 80-84.

Palil, M. R. 2010. Tax Knowledge and Tax Compliance Determinants in Self Assessment System in Malaysia. Doctoral Dissertation. Birmingham: University of Birmingham.

Palil, M. R., Akir, M. R \& Ahmad, W. F. 2013. The Perception of Tax Payers on Tax Knowledge and Tax Education with Level of Tax Compliance: A Study the Influences of Religiosity. ASEAN Journal of Economics, Management and Accounting. 1 (1): 118-129.

Torgler. 2002. Speaking to Theorists and Searching for Facts: Tax Morale and Tax Compliance in Experiments. Journal of Economics Surveys. 16 (5): 657-683. 